\title{
Colorectal Cancer pT2 TNM Finding v6 and v7
}

National Cancer Institute

\section{Source}

National Cancer Institute. Colorectal Cancer pT 2 TNM Finding v6 and v7. NCI Thesaurus. Code C60845.

Colorectal cancer with invasion into the muscularis propria. (from AJCC 6th and 7th Eds.) 